\title{
DETERMINANTS OF GRADE RETENTION IN FRANCE AND SPAIN: DOES BIRTH MONTH MATTER?
}

Running title: Birth month and Grade retention

Francisco Pedraja-Chaparro*, Daniel Santín†, Rosa Simancas*

*University of Extremadura

†Department of Applied Economics VI, Faculty of Economics and Business, Complutense University of Madrid, Campus de Somosaguas, 28223 Pozuelo de Alarcón, Madrid, Spain.

Phone: +34913942433

Fax: +34913942431

E-mail: dsantin@ccee.ucm.es

\begin{abstract}
In France and Spain, children born in the same calendar year start school together, regardless of maturity differences due to their birth month. This paper analyses the educational impact of birth month on the probability of grade retention controlling by other covariates. Using the PISA 2009 database for both countries, we do identify a great impact on grade retention since students born in the last months of the year are between $70 \%$ and $80 \%$ more likely to repeat a grade than children born in the first months of the same year. We conclude that policy interventions are required in those countries to ensure that individuals are not unfairly penalized by their birth month.
\end{abstract}

Key words: birth month, grade retention, PISA 2009, impact evaluation, economics of education

JEL codes: C21, H52, I21

\section{Introduction}

The phenomenon of grade retention in France and Spain affects around one third of all students and has become a considerable obstacle to future economic growth. According to the OECD's PISA 2009 report, over 30\% of 15-year-old students from both countries had repeated at least one grade. Several studies provide empirical evidence that students who repeat an academic year (from now on repeaters) are at greater risk of school failure, and this variable is a good predictor for early school leaving (Jimerson et al. 2002; Benito 2007; Calero et al. 2010). Therefore, this is a central issue for European governments, and the Europe 2020 strategy encourages educational policy measures to reduce school dropout rates to under $10 \%$ by 2020 . 
School failure has negative consequences for both individuals and the efficiency of the whole economy. On the one hand, early school leaving generates major labour insertion problems and a higher risk of social and economic exclusion. This is a major concern given the severity of the current European economic crisis where the unemployment level among young people is extremely high in some countries. On the other hand, school failure is associated with a lower stock of human capital and lower labour force productivity, higher social public expenditure, and lower economic growth prospects (Hanushek and Kimko 2000; Asteriou and Agiomirgianakis 2001; Psacharopoulos 2007; Duval and de la Maisonneuve 2010).

France and Spain have the ideal education system for examining the effect of birth month on student achievement, due to the fact that those students born in the same calendar year start school in the same academic year. By law, pre-primary education is optional and free from three- to five-year-olds. Compulsory education starts with primary education; pupils enter primary school in September of the year that pupils turn six, continuing for just ten years until pupils reach the age of 16 at the end of secondary education. As the cut-off date is January 1st, students born in January are almost one year older than their classmates born in December. Previous research provides evidence of a maturity gap between children born in January and December; therefore, this policy could potentially have an impact on students' future academic performance if teachers confuse maturity with learning ability (Allen and Barnsley 1993).

In this context, the aim of this paper is to evaluate whether a pupil's relative age with his/her age cohort may have a significant long-term effect on the specific problem of grade retention in the French and Spanish education systems. For the purpose of causal identification, one of the key issues of this research is to show that birth month is an exogenous variable in the analysis. To do this, we demonstrate that parents do not 
target birth dates on the basis of their children's expected future academic performance; besides, there are legal constraints preventing parents from choosing their children's enrolment cohort. Therefore, we have a natural experiment framework in which we can distinguish the cause-effect relationship between birth month and the probability of repeating any year from any accidental correlation.

As mentioned above, grade retention has a number of negative effects on students, ranging from problems of self-esteem to higher school dropout rates (Jimerson et al. 2002; Manacorda 2012; Agasisti and Cordero 2013). Were birth month found to matter, this would place a constraint not only on the efficiency of the economy of these both countries but also on the equal opportunities policy established by the Spanish and French Education Acts (Ley Orgánica de Educación and Code de l'Éducation, respectively) ${ }^{1}$, and it would justify the search for public education policies designed to avoid or reduce this problem.

The paper is structured as follows. The following section summarizes the existing literature about the analysed topic. Section 3 presents and justifies the experimental design together with the database. Section 4 presents the empirical results, and the article winds up with the main findings of this research, as well as with some educational policy proposals to reduce the birth month effect.

\section{Literature review}

There is a lot of literature on the determinants of academic performance and school failure. However, literature evaluating whether or not birth month-induced age differences in the same age cohort have a direct influence on grade retention like us is

\footnotetext{
1 Both laws state that education must ensure equal opportunities, educational inclusion and nondiscrimination. Education should act as a means to offset personal, cultural, economic and social inequalities, especially any caused by disability.
} 
harder to find. Most previous papers investigate the impact of birth month on the student outcomes ${ }^{2}$. This literature can be classified according to how the authors defined the birth month variable. Some researchers compare achievement for children born in different quarters of a year. Allen and Barnsley (1993), for example, compare percentages and apply chi-squared tests to data from a specific survey of Canadian and English schools, showing that there are educational differences by birth quarter and claiming that these differences persist and even increase in the long term. Bedard and Dhuey (2006) apply instrumental variables and also observe that initial maturity differences have long-lasting effects on student performance across some OECD countries using data from TIMSS 1995-1999. Strom (2004) compares mean scores of Norwegian students using PISA 2000 data and proves that children born in the fourth quarter of the year have lower educational results and a higher likelihood of being held back or requiring special education. Along the same lines, Sprietsma (2010) identifies a long-term (non-linear) age effect on both the probability of repeating a grade and academic outcomes using PISA 2003 data. Gutierrez-Domenech and Adserà (2012) ran a multivariate model on primary student data from a 2005 Família i Educació a Catalunya survey and likewise found that performance by younger students is poorer than for their peers and that this disadvantage does not disappear over time.

An alternative line of research followed by different authors is to restrict the sample to only older and younger students, classified according to a specific cut-off date (established by the government in order to determine children's entry to the educational system). Some examples Kawaguchi (2011), based on a regression discontinuity design with data from a Japanese labour force survey; Crawford et al. (2011), using the English National Pupil Database, and Ponzo and Scoppa (2014), exploiting the information

\footnotetext{
${ }^{2}$ The appendix to this paper summarizes previous contributions relating birth month, educational performance and grade retention.
} 
provided by PIRLS 2006, TIMSS 2007 and PISA 2009 about Italian students. They find evidence of significant differences between children born before and after the cut-off date in terms of their educational attainment, i.e. older children in the same school cohort do better than younger ones and although these differences decrease over time, they are still significant among students aged from 16 to 18 years.

The grade retention variable is usually considered as a major determinant rather than the dependent variable of educational performance. This is the line taken by Manacorda (2012), who exploits specific data from Uruguay, and Eide and Showalter (2001), also using a particular database (High School and Beyond). Both papers report the negative impact of grade retention on educational performance, causing higher dropout rates and lower future earnings. The same issue is analysed by Calero et al. (2010) for Spain concluding that grade retention significantly explains low educational performance calling into question grade retention as an efficient strategy for reducing the risk of school failure.

There is substantially less research and literature targeting our objective: analyse the influence of birth month on the probability of repeating a year. Corman (2003) studies the influence of certain variables (including students' birth month) on the probability of retention through a multivariate probit analysis using the United States National Household Education Survey database; the conclusion is that children born in the fourth quarter of the year are six percentage points more likely to repeat a grade than children born in the first quarter. In Spain, Calero (2006) applies a multinomial logistic model using EU Household Panel data and sets a four-level dependent variable: 'in compulsory secondary education or primary education' (this represents the group of repeater students), ${ }^{3}$ 'in post-compulsory education', 'in intermediate vocational training

\footnotetext{
${ }^{3}$ The reason is that these students should have completed compulsory education by that age.
} 
or 'in work'. The birth month is introduced in the model as a dummy variable (children born in the last quarter of the year compared to others), and the research reports that the youngest students in the same school cohort have greater learning difficulties, which increases their probability of repeating a year. All things considered, this paper contributes to existing research by providing evidence of the effect of birth month on the probability of 15-year-old students from Spain and France repeating a grade.

\section{Research design}

\subsection{Data}

The dataset used for the research comes from the PISA (Programme for International Student Assessment) survey, designed and implemented by the OECD in the late 1990s as a comparative, international, regular and continuous study of certain characteristics and skills of students worldwide (Turner 2006). The PISA target population is composed of students aged between 15 and 16 years at the time of the assessment, all of whom are born in the same year and who have completed at least six years of formal schooling. PISA measures their performance in math, reading, and science. It also gathers information about students' personal background and school environment, for which purpose two questionnaires are administered, one addressed to school principals and another to students themselves. ${ }^{4}$ These surveys have taken place every three years since 2000 focusing on one of the above three competences each year.

An important aspect to be taken into account in an empirical analysis using PISA data is that the data are gathered by means of a two-stage sampling procedure. First, a sample of schools is selected in every country from the full list of schools containing the

\footnotetext{
${ }^{4}$ Parents complete a third questionnaire. However, this information is only available for a limited number of countries and, unfortunately, Spain is not one. Besides, school data for France were not available because the school questionnaire was not administered (OECD, 2010).
} 
total student population. Then, a sample of 35 students is randomly selected within each school. As a result, statistical analyses have to consider sampling weights to ensure that students adequately represent the analyzed total population (Rutkowski et al. 2010) ${ }^{5}$. Our sample is composed of 25,887 students from 889 schools from Spain and 4,298 students from 168 schools from France that took part in PISA 2009 (OECD 2010).

\subsection{Is birth month exogenously distributed?}

The key variable in this research is the students' birth month (BM). First of all, we need to find out whether this variable is exogenously distributed among students regardless of other factors or, on the contrary, parents target their children's birth date with the aim of maximizing their future academic performance. In this last case, most births should occur in the first few months of the natural year, and fewer births should be observed at the end.

We use a Kolmogorov-Smirnov test to check for a uniform distribution that would demonstrate the exogeneity of the birth month variable. We compare the observed distribution of births in 1993 (birth year of the student respondents) to the expected distribution of births according to the average daily births in that year based on the information provided by PISA 2009. Table 1 reports both distributions, and Figure 1 plots the monthly deviation in the number of observed births with respect to their expected distribution over the year for both countries.

\footnotetext{
${ }^{5}$ These weights include adjustments for non-response by some schools and students within schools and weight cutting to prevent a small set of schools or students having undue influences. These processes are based on intensive calculation methods, known as "resampling" methods, which consist of taking multiple samples from the original sample. Specifically, PISA uses the Balanced Repeated Replication (BRR) with 80 replicates. For an extensive description of this procedure, see (OECD, 2005, 2009).
} 
Table 1. Observed and expected distribution of births by months.

\begin{tabular}{lcc|cc}
\hline & \multicolumn{2}{c|}{ SPAIN } & \multicolumn{2}{c}{ FRANCE } \\
\hline Month & Expected & Observed & Expected & Observed \\
\hline January & 2,199 & 2,096 & 365 & 317 \\
February & 1,986 & 1,908 & 330 & 333 \\
March & 2,199 & 2,122 & 365 & 320 \\
April & 2,128 & 2,162 & 353 & 350 \\
May & 2,199 & 2,204 & 365 & 370 \\
June & 2,128 & 2,069 & 353 & 379 \\
July & 2,199 & 2,303 & 365 & 371 \\
August & 2,199 & 2,160 & 365 & 396 \\
September & 2,128 & 2,352 & 353 & 343 \\
October & 2,199 & 2,160 & 365 & 362 \\
November & 2,128 & 2,177 & 353 & 372 \\
December & 2,199 & 2,176 & 365 & 385 \\
\hline Total & 25,887 & 25,887 & 4,298 & 4,298 \\
\hline
\end{tabular}

As Table 1 shows, the expected number of births is not exactly the same every month because months contain different numbers of days. The Kolmogorov-Smirnov test finds that both distributions are similar at a 95\% confidence level in Spain and France $(p$-value $=0.391$ and $p$-value $=0.100$, respectively). This finding confirms that births are randomly distributed throughout the year, and hence we consider birth month to be an exogenous random variable. From this result, we can conclude that parents in these two countries do not plan their children's birth date with the aim of improving their educational outcomes. ${ }^{6}$

Figure 1 shows that the observed and expected distributions of births are clearly similar in both countries. The real number of births is slightly higher than expected in the summer months both in Spain and in France. These births may be planned for the purpose of adding the holiday month on to the maternity leave period.

\footnotetext{
${ }^{6}$ We also carried out a one-way analysis of variance to find out if we could reject equal mean socioeconomic levels (the ESCS variable is defined in Section 3.4.) by birth month. The results of the pairwise comparison Bonferroni tests were not statistically significant at a $95 \%$ confidence level, further corroborating the conclusion that birth month is exogenously determined both in Spain and France regardless of socioeconomic status.
} 
Figure 1. Monthly deviation in observed births with respect to expected births.

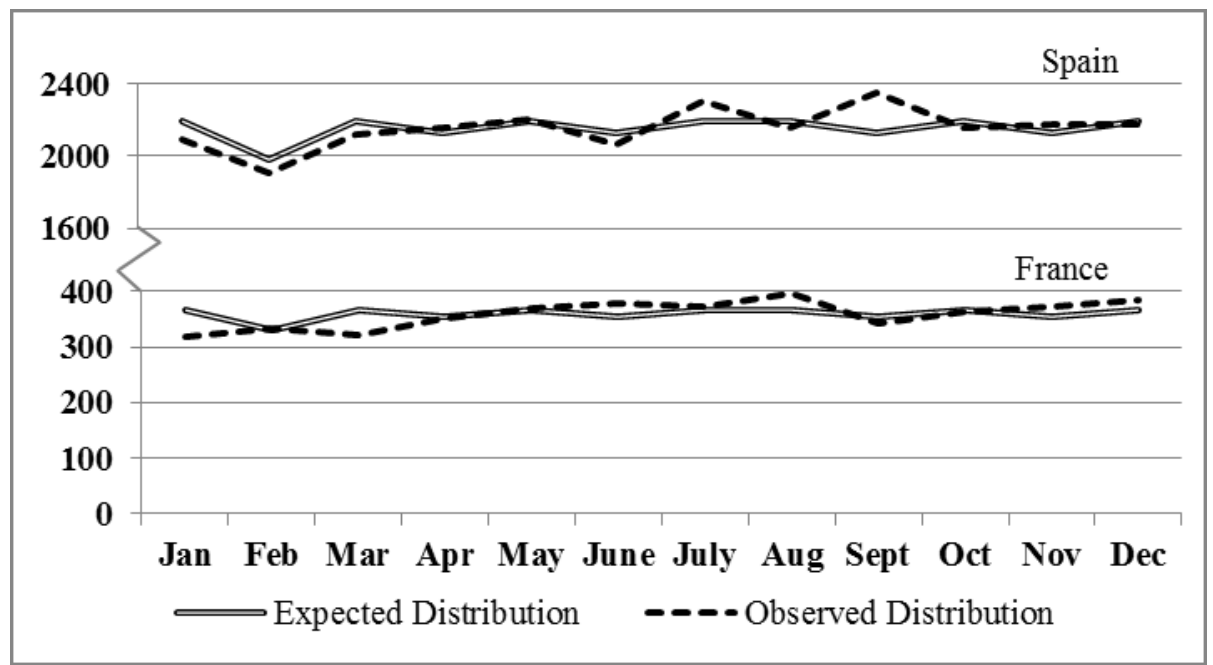

\subsection{Birth month and grade retention}

As already mentioned, the educational legislation on school starting age establishes that one cohort must be composed of every student born in the natural year, and this is the only option open to parents ${ }^{7}$. Therefore, we have a 'natural experiment' because the birth month appears to be an exogenous variable with respect to the dependent variable considered in this research: the probability of having repeated a grade at the end of secondary education.

Instead of assuming a hypothetical year division like other researchers, we first set out to discover the shortest period of time, in months, that showed up statistically significant differences with respect to its nearest alternatives. In other words, how many months have to be aggregated to find statistical significant differences in grade retention? For this purpose, we explore several cross tabulations (one cross-tab for every possible child grouping by birth month: monthly, bimonthly, quarterly, and so on) in order to compare the percentages of repeaters among pupils born at different times of the same calendar year. If our hypothesis that birth month influences the probability of

\footnotetext{
${ }^{7}$ Legally, parents cannot keep their children at a pre-primary level for an additional year or postpone their children's entry to the first year of primary school.
} 
repeating a grade is true, there should be an upward trend in the percentages of repeaters as the year progresses, since children born earlier in the year are less likely to repeat a grade than students born later in the same year. At the same time, these percentages should be statistically and significantly different from each other.

In order to check their statistical significance, we use a chi-squared test with (r1) (c-1) degrees of freedom ( $\mathrm{r}$ denotes number of rows and $\mathrm{c}$ denotes number of columns) at a 95\% confidence level, which is useful for testing the equality of proportions (eq. 1):

$$
{ }_{(r-1)(c-1) ; 0,05}^{2}=\sum_{i j} \frac{\left(f_{i j}-E_{i j}\right)^{2}}{E_{i j}},
$$

where $f_{i j}$ represents the observed frequency and $E_{i j}$ is the expected frequency ${ }^{8}$. If this test rejects the null hypothesis (i.e. at least one proportion is different from any other), we run a chi-squared test by cell in order to determine where the differences are. On this occasion, we employ a chi-squared test with one degree of freedom again at a $95 \%$ confidence level. In this research, we are interested in only the shortest period of time that shows up statistically significant differences in every cell. The shortest periods of time that meets all the above requirements are the bimester, i.e. a bi-monthly aggregation of the births throughout the year for Spain and the quarter for France ${ }^{9}$. Results of repeaters depending on the aggregation of months are shown in Table 2.

Grade retention rates for pupils born in the last months of the year are clearly over 10 points higher than for pupils born in the first months, being the influence of the

\footnotetext{
${ }^{8}$ The expected frequency for the cell in the $i^{\text {th }}$ row and the $j^{\text {th }}$ column is the total number of subjects in row $i$ by the total number of subjects in column $j$, divided by the total number of subjects in the whole table.

${ }_{9}$ Note that all time periods longer than a bimester for Spain and the quarter for France met the requirement as well.
} 
birth slightly higher in Spain (14 points) than in France (12 points). However, this is not a linear increment: the average increase in the first half of the year is 1.63 percentage points for Spain and 1.1 percentage points for France, rising to 3.39 and 2.91 percentage points, respectively, in the last half). A preliminary conclusion related to this result is that the influence of the birth month becomes more pronounced as the year advances. Figure 2 illustrates the above phenomenon.

Table 2. Percentage of repeaters and non-repeaters by birth bimester (Spain) and birth quarter (France).

\begin{tabular}{lcc}
\hline \multicolumn{1}{c}{ Spain } & Repeater & Non Repeater \\
\cline { 1 - 2 } Bimester & $30.35 \%$ & $69.65 \%$ \\
January-February & $32.55 \%$ & $67.45 \%$ \\
May-June & $33.61 \%$ & $66.39 \%$ \\
July-August & $37.24 \%$ & $62.76 \%$ \\
September-October & $40.83 \%$ & $59.17 \%$ \\
November-December & $44.01 \%$ & $55.99 \%$ \\
\hline Total & $36.56 \%$ & $63.44 \%$ \\
\hline & & \\
\hline & Repeater & Non Repeater \\
\hline Quarter & $33.70 \%$ & $66.30 \%$ \\
\hline January-March & $35.90 \%$ & $64.10 \%$ \\
April-June & $40.39 \%$ & $59.61 \%$ \\
July-September & $46.21 \%$ & $53.79 \%$ \\
October-December & $39.25 \%$ & $60.75 \%$ \\
\hline Total & & \\
\hline
\end{tabular}

Figure 2. Distribution of repeater students by bimester of birth (Spain) and quarter of birth (France). 

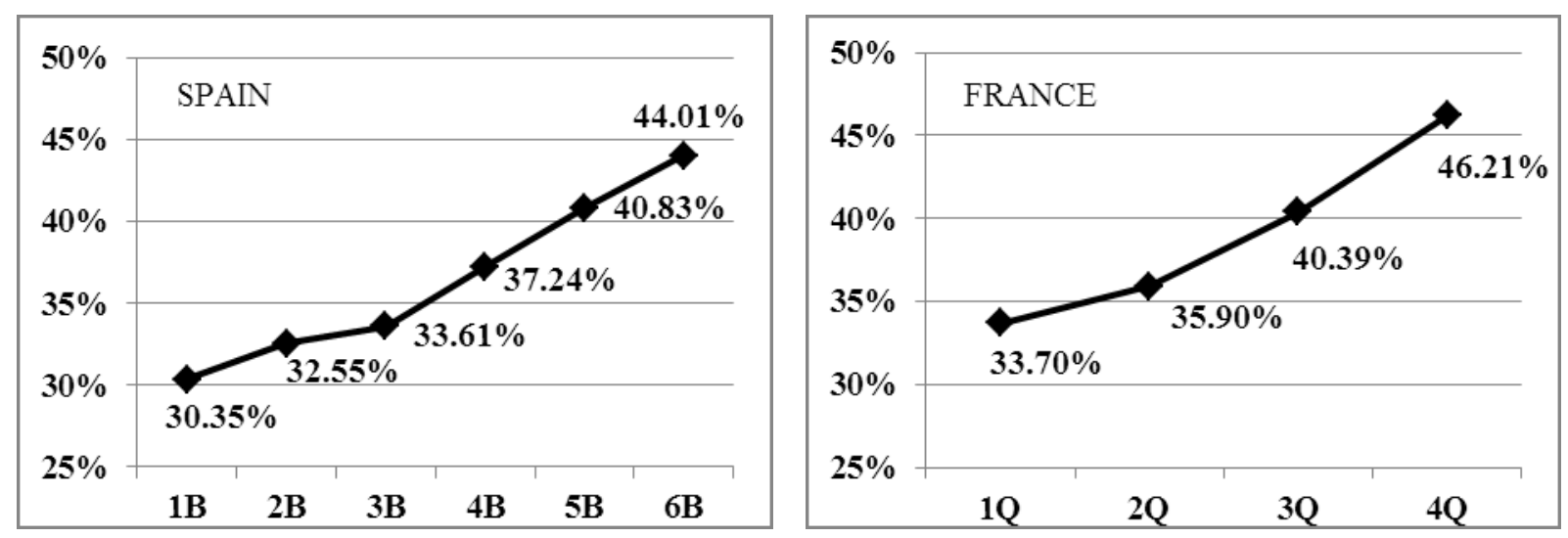

$* B$ denotes Bimesters, from the first one (1B: January-February) to the last one (6B: November-December).

**Q denotes Quarters, from the first one (1Q: January-February-March) to the last one (4Q: October-November-December)

\subsection{Variables}

We have already analysed the influence of birth month on the probability of having repeated a grade by the age of 15 years, comparing percentages of repeaters and non-repeaters depending on their birth month. Nevertheless, this methodology can be extended to account for other control variables related to pupils, families, and schools, which may also have an impact on the dependent variable. For this purpose, we estimate a logistic regression including several control variables related to students' background apart from birth month. Logistic regression coefficients are especially useful for estimating odds ratios for each independent variable in the model. Odds ratios measure the probability of an event occurring over the probability of it not occurring. The regression we estimate is as follows (Eq. 2):

$$
\operatorname{Prob}\left(R_{i s}=1\right)=\frac{e^{\alpha+\beta_{1} B M_{i s}+\beta_{2} X_{i s}}}{1+e^{\alpha+\beta_{1} B M_{i s}+\beta_{2} X_{i s}}}=\frac{1}{1+e^{-\left(\alpha+\beta_{1} B M_{i s}+\beta_{2} X_{i s}\right)}},
$$

where $R_{i s}$ denotes whether the student $i$ in school $s$ is a repeater $\left(R_{i s}=1\right)$ or not $\left(R_{i s}=0\right)$, $B M_{i s}$ is the student's birth month and $X_{i s}$ is the vector of control variables.

Regarding the variables, we use $R_{i s}$ as a dependent variable. At 15 years old students are approaching the end of both Spanish and French compulsory education. 
The Spanish students should be in their 4th grade of ESO (Enseñanza Secundaria Obligatoria, compulsory secondary education in the Spanish education system), while French pupils should be in the 1st year of Lycée (senior high school in the French education system). Both of them are equivalent to 10 th grade on the international scale, hence we consider that 15-year-old students who are not in 10th grade are repeaters.

The key variable referred to students' birth month, $B M_{i s}$, is aggregated bimonthly in the case of Spain and quarterly in the French analysis. In short, there are six categories classifying Spanish students according to the month in which they were born as follows: 'BM: January-February' represents students born in January and February, 'BM: March-April' represents students born in March and April, and so on where the first bimester is the baseline category. At the same time, four categories are defined to classify French students depending on their quarter of birth, for example, 'Q: January-March' represents students born between January and March. The remaining categories are 'Q: April-June', 'Q: July-September' and 'Q: October-December', being the first quarter the baseline category.

The set of control variables, which are exogenous with respect to the dependent variable and that will be introduced in the logistic regression model are:

Index of economic, social, and cultural status (ESCS): This is an index created by PISA from three variables related to the highest occupational status of parents, the highest educational level of parents in years of education according to ISCED, and educational possessions at home.

Gender: This variable will take the value 1 for boys and 0 for girls.

Immigrant status: This variable has the following categories: 'native students' are students born in the country of analysis or students with at least one parent born in that country (which is the baseline category), 'second-generation immigrants' are 
students born in the country of analysis but whose parents were born in another country, and 'first-generation immigrants' are foreign-born students whose parents are also foreign-born. Students with missing responses for either their origin or their parents' origin have been saved in the category named 'uncertain origin', assuming that their refusal to answer these questions is because they have reasons for not wanting to disclose this information (Salinas and Santín 2012).

Pre-primary attendance: All countries participating in PISA show a positive relationship between the proportion of students who received pre-primary education and average school system performance, even after accounting for the socioeconomic status (OECD 2011). It is a four-category variable: 'pre-primary: non-attendance, students who report not having received pre-primary education; 'pre-primary: one year or less', students who attended pre-primary school for less than a year; and 'pre-primary: over a year', students who reported having attended pre-primary school for more than a year (which is the baseline category).

Family structure: Several studies highlight the influence of family situation on student performance. This variable is divided in three categories: 'single-parent family' composed of one parent and his/her children; 'mixed family' consisting of a couple in which one family member has children from a previous relationship; and 'nuclear family' composed of both parents and their children (which is the baseline category).

\section{Results}

As mentioned in Section 3, we estimate two logistic regression models, one for each country. In both models, the dependent variable is the repeater status at age $15(\mathrm{R})$ and the key explanatory variable is, on the one hand, the bimester of birth (BM) in the Spanish estimation and on the other hand, the quarter of birth (Q) in the French analysis. 
In addition to this variable, we include the set of control variables defined in Section 3.4 related to individual and socioeconomic characteristics. Table 3 reports the parameters obtained when we estimate the models for both countries.

Table 3. Models results.

\begin{tabular}{|c|c|c|c|c|c|c|c|}
\hline \multicolumn{4}{|c|}{ SPAIN } & \multicolumn{4}{|c|}{ FRANCE } \\
\hline Variables & Coeffici & ents & Odds ratio & Variables & Coeffic & ients & Odds ratio \\
\hline Constant & -1.648 & $* * *$ & & Constant & -1.234 & $* * *$ & 0.291 \\
\hline BM:Mar-Apr & 0.085 & & 1.088 & Q:Apr-June & 0.095 & & 1.100 \\
\hline BM:May-June & 0.179 & $* *$ & 1.196 & Q:July-Sept & 0.276 & $* * *$ & 1.317 \\
\hline BM:July-Aug & 0.297 & $* * *$ & 1.346 & Q:Oct-Dec & 0.529 & $* * *$ & 1.698 \\
\hline BM:Sept-Oct & 0.502 & $* * *$ & 1.653 & & & & \\
\hline BM:Nov-Dec & 0.617 & $* * *$ & 1.854 & & & & \\
\hline ESCS & -0.676 & $* * *$ & 0.509 & ESCS & -0.800 & $* * *$ & 0.449 \\
\hline Gender: Boy & 0.488 & $* * *$ & 1.629 & Gender: Boy & 0.525 & $* * *$ & 1.690 \\
\hline $\begin{array}{l}\text { Immigrant Status: } \\
\text { 2nd Gen }\end{array}$ & 0.470 & $* *$ & 1.599 & $\begin{array}{l}\text { Immigrant Status: } \\
\text { 2nd Gen }\end{array}$ & 0.173 & & 1.188 \\
\hline $\begin{array}{l}\text { Immigrant Status: } \\
\text { 1st Gen }\end{array}$ & 1.236 & $* * *$ & 3.440 & $\begin{array}{l}\text { Immigrant Status: } \\
\text { 1st Gen }\end{array}$ & 0.567 & $* *$ & 1.763 \\
\hline $\begin{array}{l}\text { Immigrant Status: } \\
\text { Uncertain }\end{array}$ & 0.794 & $* * *$ & 2.212 & $\begin{array}{l}\text { Immigrant Status: } \\
\text { Uncertain }\end{array}$ & 0.417 & & 1.517 \\
\hline Pre-primary: No & 0.444 & $* * *$ & 1.559 & Pre-primary: No & 0.892 & $* *$ & 2.441 \\
\hline $\begin{array}{l}\text { Pre-primary: } \\
\leq 1 \text { year }\end{array}$ & 0.421 & $* * *$ & 1.523 & $\begin{array}{l}\text { Pre-primary: } \\
\leq 1 \text { year }\end{array}$ & 0.633 & $* * *$ & 1.883 \\
\hline $\begin{array}{l}\text { FamStruc: } \\
\text { Single-parent }\end{array}$ & 0.470 & $* * *$ & 1.600 & $\begin{array}{l}\text { FamStruc: } \\
\text { Single-parent }\end{array}$ & 0.207 & $* *$ & 1.230 \\
\hline FamStruc: Mixed & 1.106 & $* * *$ & 3.021 & FamStruc: Mixed & 1.673 & $* * *$ & 5.328 \\
\hline
\end{tabular}

Dependent variable: To be a repeater; $* *$ significant at $95 \%$ level; $* * *$ significant at $99 \%$ level

Our main variable of interest: birth month appears to be a clearly significant factor and plays an important role in the probability of the assessed students being repeaters both in Spain and in France. In both analyses, the associated odds ratios are greater than one and higher as the year advances. This evidences the increased probability of repeating versus not repeating a grade. Regarding Spanish pupils, after the introduction of controls, there is still a difference between children born in January and February with respect to students born in March and April but it is no longer 
significant. The results for France show that a similar effect is applied on French pupils. Although a difference between children born in the first and the second quarter of the year still exist, it is not statistically significant either. From this point on, every student born in the following bimesters (quarters) is significantly more likely to be a repeater at the age of 15 than their peers born in the first bimester (quarter). For example, children born in the third bimester (May and June) are 20 percentage points more likely to repeat a grade than children born in the first two months. More importantly, students born in the last two months of the year (November and December) have an $85 \%$ greater probability of repeating a year than their classmates born in January and February. This impact, although still high, is lower in France. For a child born in the fourth quarter of the year, his/her chance of repeating a grade increases by about $70 \%$ respect to a child born in the first quarter of the same year. The results obtained for Spain and France strongly indicate that being the older in the same cohort is a definite advantage in terms of repeating a grade. This result is consistent with the findings of Bedard and Dhuey (2006) for the United States, Calero (2006) for Spain, Crawford et al. (2011) for England, and Sprietsma (2010) for OECD countries, who all argue that being the oldest rather the youngest in the age cohort reduces the probability of grade retention.

Regarding control variables, findings are consistent with the results reported in the literature reviewed previously. Students' socioeconomic status has a negative and significant relationship with probability of grade retention in both countries, being the negative impact slightly lower in France; whereas boys are over $60 \%$ more likely to repeat a grade than girls in the two education systems.

The immigrant status seems to be statistically significant and positively related to the dependent variable in both countries. However, the impact of being an immigrant is extremely higher in Spain. Among the immigrant-related variables, being a first- 
generation immigrant leads to clearly more probability of repeating a grade in Spain while being a second-generation immigrant do not have statistically significant effect on the French education system. These results might be due to the fact that France has been a traditionally immigrant-receiving country compared to Spain, where the remarkable increase of the foreign population has taken place over the last 15 years. The value of the odds ratio associated with students classified as of 'uncertain origin' is positioned mid-way between the values for first- and second-generation immigrants, which could indicate that students from this category are members of the other two groups.

Both in Spain and in France, pre-primary school attendance is positively and significantly related to the probability of repeating a grade. Thus, children who received or one year's or less or no pre-primary education are more likely to repeat a grade than children who attended pre-primary school for more than a year, although the penalty of not attending pre-primary school is larger in France. Noteworthy too is that family structure has a significant effect in both neighbouring countries. Children living in mixed families are more likely to repeat a year than members of single-parent families, and both more than children living in a nuclear family, although the magnitude of the impact is somewhat lower in Spain ${ }^{10}$.

All in all, these outcomes are consistent with findings by Corman (2003, p. 417) for the United States, which he summarizes as follows. 'Boys are more likely to repeat a grade than girls. In addition, children who come from poorer households or who come from single-parent households are all at greater risk of failing in school'.

\footnotetext{
10 An additional interesting result for Spain is that children enrolled in private schools or private government-dependent schools are less likely to repeat a year than pupils enrolled in public schools. These results suggest that such large differences in terms of grade retention probability depending on school ownership might be due not only to a different system of management but also to each school type establishing different internal requirements for deciding whether or not children should repeat a grade. It was no possible to run the same analyses for France due to the lack of this school information in this country.
} 


\section{Conclusions and Policy Implications}

The phenomenon of grade retention is now a major problem in countries such as France or Spain. According to the PISA 2009 report, over 30\% of 15 -year-old students from both countries had repeated at least one grade. These figures are a warning sign of school failure and early school dropout, whose percentages are consistent with grade retention rates. The consequences of this situation are negative for both individuals and the economy as a whole and even more so in the current economic crisis.

The aim of this paper is to examine the possible influence of birth month on the likelihood of having repeated a year by the age of 15 in France and Spain. For this purpose, we use the data provided by the PISA 2009 report. Our first conclusion is that, at least for these two countries, the birth month variable is exogenously distributed with respect to the probability of being a repeater. Regardless of socioeconomic status, Spanish and French parents do not plan the birth of their children at the beginning of the year based on expected educational outcomes, as evidenced by the fact that the observed distribution of births in 1993 (birth year of the assessed students) was statistically similar to the expected distribution, at a $95 \%$ confidence level.

Concerning the influence of birth month on grade retention, the first statistically significant differences appear with a bimonthly aggregation for Spain and a quarterly aggregation for France. In both countries, the retention rate of children born in last months of the year is over 10 percentage points higher than retention rate of students born in the first months of the same year, being this difference greater in Spain than in France. Note also that this is a non-linear increase, because the influence of the birth month becomes more pronounced as the year progresses and particularly in the last semester in the two education systems. 
In order to control by other variables that are also likely to influence the probability of repeating a year, we estimate a logistic regression model for each country. The findings show that birth month is statistically and significantly related to the dependent variable. The later students are born in the year, the greater is the increase in their probability of repeating versus not repeating a grade, which ranges from $19 \%$ (May-June bimester) to $85 \%$ (November-December bimester) for Spanish pupils and from $32 \%$ (third quarter of the year) to $70 \%$ (last quarter of the year) for French pupils. No significant differences are found for children born between January and April after controlling for other variables. Other interesting results suggest that other factors related to the increased likelihood of repeating a grade are lower household educational level and income, male gender, immigrant status (above all first-generation immigrant students), not having received pre-primary schooling or living in a non-nuclear family.

According to these findings, the French education system seems to be more equitable than the Spanish one, because in France the penalty of coming from disadvantaged backgrounds is lower than in Spain. At the same time, a specific program to help pupils who did not attend pre-primary school to reach the performance of pupils who did it would be needed in the French education system, in order to reduce the higher negative effect found on grade retention.

Interestingly, maturity differences at early ages (due to birth month) are significant at the end of secondary education. This result implies that birth month has a sizeable and persistent effect on educational performance. Such findings suggest that there is a need for innovative educational strategies to solve this problem. Both France and Spain have settled for an inflexible admission rule, where children born between January 1 st and December 31 st of the same year have to enrol in the same grade at school. As there is no general public intervention for students born at the end of the 
year, there are maturity differences among children at the same class because of a near one-year age gap between children born at the beginning and end of the same year.

Authors like Strom (2004), Crawford et al. (2011) or Sprietsma (2010) advocate a more flexible rule, according to which parents should be able to choose when to enrol their children, especially if they were born at the end of the year. According to our results, an alternative policy for this issue would be to give parents of children born at the beginning and at the end of the year (i.e. the oldest and the youngest children in each cohort) the opportunity to decide whether their children should move up or down a year, respectively. The provision of additional tuition to offset the initial disadvantages of the youngest students in the class or the doubling of primary education classes with the aim of reducing age gaps from 12 to 6 months are other alternatives proposed by GutiérrezDomènech and Adserà (2012) and Ponzo and Scopa (2014).

This research provides evidence that there is a clear problem that both Spanish and French educational authorities need to solve. The educational disadvantage incurred by the youngest pupils in their academic cohort should be viewed as a serious concern. On this ground, some policy intervention is needed to ensure that individuals are not unfairly penalized by their birth month, as it is unacceptable in terms of efficiency and equal educational opportunities.

Acknowledgements We would like to thank the Consejería de Empleo, Empresa e Innovación (Extremadura Regional Government) and the European Social Fund for providing a pre-doctoral fellowship for Rosa Simancas (DOE No. 130 de 08/07/2010). Research support from the Extremadura Government (Project IB13106) is also acknowledged.

\section{Appendix: Literature review}

\begin{tabular}{llll}
\hline AUTHOR OBJECTIVE & DATABASE
\end{tabular}




\begin{tabular}{|c|c|c|c|}
\hline $\begin{array}{l}\text { Allen \& Barnsley } \\
\text { (1993) }\end{array}$ & $\begin{array}{l}\text { Analyse whether } \\
\text { streaming at early ages } \\
\text { has a long-term effect on } \\
\text { the educational } \\
\text { performance of Canadian } \\
\text { and British students }\end{array}$ & $\begin{array}{l}\text { Two specific surveys for } \\
\text { Canadian Hockey } \\
\text { League and for Canadian } \\
\text { and British students }\end{array}$ & $\begin{array}{l}\text { There are educational } \\
\text { differences by birth } \\
\text { quarter, and these } \\
\text { differences persist and } \\
\text { even increase in the long } \\
\text { term }\end{array}$ \\
\hline $\begin{array}{l}\text { Eide \& Showalter } \\
\text { (2001) }\end{array}$ & $\begin{array}{l}\text { Analyse the influence of } \\
\text { grade retention on the } \\
\text { probability of dropping } \\
\text { out of high school and on } \\
\text { labour market earnings }\end{array}$ & $\begin{array}{l}\text { High School and Beyond } \\
\text { from United States }\end{array}$ & $\begin{array}{l}\text { Grade retention causes } \\
\text { higher drop-out rates and } \\
\text { lower future earnings }\end{array}$ \\
\hline Corman (2003) & $\begin{array}{l}\text { Examine the effects of } \\
\text { state education policies, } \\
\text { and individual, family } \\
\text { and neighbourhood } \\
\text { characteristics on grade } \\
\text { retention in USA }\end{array}$ & $\begin{array}{l}\text { National Household } \\
\text { Education Survey 1991, } \\
\text { 1993, 1995, } 1996\end{array}$ & $\begin{array}{l}\text { Children born in the } \\
\text { fourth quarter of the year } \\
\text { are more likely (around } 6 \\
\text { percentage points) to } \\
\text { repeat a grade than } \\
\text { children born in the first } \\
\text { quarter }\end{array}$ \\
\hline Strom (2004) & $\begin{array}{l}\text { Estimate the effect of } \\
\text { age at school entry on } \\
\text { school achievement for } \\
15-\text { to } 16 \text {-year-old } \\
\text { students in Norway }\end{array}$ & PISA 2000 & $\begin{array}{l}\text { Children born in the } \\
\text { fourth quarter of the year } \\
\text { have lower educational } \\
\text { results and a higher } \\
\text { likelihood of being held } \\
\text { back or requiring special } \\
\text { education }\end{array}$ \\
\hline $\begin{array}{l}\text { Bedard \& Dhuey } \\
(2006)\end{array}$ & $\begin{array}{l}\text { Analyse the effect of age } \\
\text { at school entry on } \\
\text { educational outcomes for } \\
\text { 9-year-old and 13-year- } \\
\text { old Canadian and } \\
\text { American students }\end{array}$ & $\begin{array}{l}\text { TIMNSS } 1995 \\
\text { TIMNSS } 1999\end{array}$ & $\begin{array}{l}\text { Relative age effects } \\
\text { disappear over time, } \\
\text { although retain a marginal } \\
\text { effect into adolescence }\end{array}$ \\
\hline Calero (2006) & $\begin{array}{l}\text { Study the determinants } \\
\text { of the low rate of } \\
\text { individuals with post- } \\
\text { secondary education } \\
\text { finished }\end{array}$ & $\begin{array}{l}\text { European Union } \\
\text { Household Panel Data } \\
\text { for Spain (PHOGUE) }\end{array}$ & $\begin{array}{l}\text { Children born in the last } \\
\text { quarter of the year have } \\
\text { learning disabilities, so } \\
\text { that their likelihood of } \\
\text { repeating a grade } \\
\text { increases }\end{array}$ \\
\hline $\begin{array}{l}\text { Calero, Choi \& } \\
\text { Waisgrais (2010) }\end{array}$ & $\begin{array}{l}\text { Detect the determinants } \\
\text { of school failure in Spain }\end{array}$ & PISA 2006 & $\begin{array}{l}\text { The grade retention policy } \\
\text { is not an effective strategy } \\
\text { for reducing the risk of } \\
\text { school failure }\end{array}$ \\
\hline Sprietsma (2010) & $\begin{array}{l}\text { Analyse the effect of } \\
\text { relative age on the } \\
\text { academic results of 15- } \\
\text { year-old students } \\
\text { through an international } \\
\text { comparison }\end{array}$ & PISA 2003 & $\begin{array}{l}\text { There is a long-term } \\
\text { (non-linear) impact on } \\
\text { academic results and on } \\
\text { grade retention }\end{array}$ \\
\hline Kawaguchi (2011) & $\begin{array}{l}\text { Analyse the effect of } \\
\text { birth month on } \\
\text { educational attainment } \\
\text { and labour market } \\
\text { outcomes for Japanese } \\
\text { students }\end{array}$ & $\begin{array}{l}\text { TIMSS } 2003 \\
\text { Employment } \\
\text { Survey } 2002\end{array}$ & $\begin{array}{l}\text { Older children in same } \\
\text { school cohort do better } \\
\text { than younger ones in } \\
\text { primary school and these } \\
\text { initial advantage persist } \\
\text { and develops into a } \\
\text { difference in eventual } \\
\text { educational attainment }\end{array}$ \\
\hline
\end{tabular}




\begin{tabular}{|c|c|c|c|}
\hline $\begin{array}{l}\text { Crawford, Dearden } \\
\& \text { Meghir (2011) }\end{array}$ & $\begin{array}{l}\text { Evaluate the impact of } \\
\text { birth month on the } \\
\text { academic performance of } \\
\text { 5-year-old and 8-year- } \\
\text { old students and what its } \\
\text { causes are }\end{array}$ & $\begin{array}{l}\text { English National Pupil } \\
\text { Database }\end{array}$ & $\begin{array}{l}\text { Older students in each } \\
\text { school cohort have higher } \\
\text { average results and these } \\
\text { differences remain in the } \\
\text { long term }\end{array}$ \\
\hline Manacorda (2012) & $\begin{array}{l}\text { Measure the effect of } \\
\text { grade retention on } \\
\text { students' } \\
\text { school } \\
\text { outcomes }\end{array}$ & $\begin{array}{l}\text { Specific database from } \\
\text { Uruguay }\end{array}$ & $\begin{array}{l}\text { Negative impact of } \\
\text { retention on educational } \\
\text { performance }\end{array}$ \\
\hline $\begin{array}{l}\text { Gutiérrez-- } \\
\text { Domènech \& } \\
\text { Adserà (2012) }\end{array}$ & $\begin{array}{l}\text { Analyse the effect of } \\
\text { personal } \\
\text { socioeconomic } \\
\text { characteristics on the } \\
\text { academic achievement of } \\
\text { 2nd--, 4th- and 6th- } \\
\text { grade } \\
\text { students }\end{array}$ & $\begin{array}{l}\text { Família i Educació a } \\
\text { Catalunya } 2005\end{array}$ & $\begin{array}{l}\text { Children born at the end } \\
\text { of the year have lower } \\
\text { academic achievement, } \\
\text { and this disadvantage does } \\
\text { not disappear over time }\end{array}$ \\
\hline $\begin{array}{l}\text { Ponzo \& Scopa } \\
\text { (2014) }\end{array}$ & $\begin{array}{l}\text { Evaluate the effect of } \\
\text { age at school entry on } \\
\text { school performance of } \\
4^{\text {th }}, 8^{\text {th }} \text { and } 10^{\text {th }} \text { grade } \\
\text { Italian students }\end{array}$ & $\begin{array}{l}\text { PIRLS } 2006 \\
\text { TIMSS } 2007 \\
\text { PISA } 2009\end{array}$ & $\begin{array}{l}\text { Younger children score } \\
\text { lower than their older } \\
\text { peers and that advantage } \\
\text { remains into adolescence }\end{array}$ \\
\hline
\end{tabular}

\section{References}

Agasisti, T. and Cordero, J. (2013) Educational disparities across regions: A multilevel analysis for Italy and Spain. Journal of Policy Modeling 35:1079-1102.

Allen, J. and Barnsley, R. (1993) Streams and Tiers: The interaction of ability, maturity, and training in systems with age-dependent recursive selection. Journal of Human Resources 28:649-659.

Asteriou, D. and Agiomirgianakis, G. M. (2001) Human capital and economic growth: Time series evidence from Greece. Journal of Policy Modeling 23:189-481.

Bedard, K. and Dhuey, E. (2006) The persistence of early childhood maturity: International evidence of long-run age effects. Quarterly Journal of Economics $121: 1437-1472$.

Benito, A. (2007) La LOE ante el fracaso, la repetición y el abandono escolar. Revista Iberoamericana de Educación 43:1-11. 
Calero, J. (2006) Desigualdades tras la educación obligatoria: nuevas evidencias. Working Paper 83/2006, Fundación Alternativas, Madrid.

Calero, J., Choi, A. and Waisgrais, S. (2010) Determinantes del riesgo de fracaso escolar en España: Una aproximación a través de un análisis multinivel aplicado a PISA 2006. Revista de Educación extra number 2010: 225-256.

Corman, H. (2003) The effects of state policies, individual characteristics, family characteristics, and neighbourhood characteristics on grade repetition in the United States. Economic of Education Review 22:409-420.

Crawford, C., Dearden, L. and Greaves, E. (2011) Does When You Are Born Matter? The Impact of Month of Birth on Children's Cognitive and Non-Cognitive Skills in England. Institute for Fiscal Studies IFS Briefing Note 122, London.

Duval, R. and de la Maisonneuve, C. (2010) Long-run growth scenarios for the world economy. Journal of Policy Modeling 32:64-80.

Eide, E.R. and Showalter, M.H. (2001) The effect of grade retention on educational and labor market outcomes. Economic of Education Review 20:563-576.

Gutiérrez-Domènech, M. and Adserà, A. (2012) Students performance in elementary schools. Revista de Economía Aplicada 59:135-164.

Hanushek, E.A. and Kimko, D.D. (2000) Schooling, labour-force quality, and the growth of nations. American Economic Review 90:1184-1208.

Jimerson, S.R., Anderson, G.E. and Whipple, A.D. (2002) Winning the battle and losing the war: Examining the relation between grade retention and dropping out of high school. Psychology in the School 39:441-457.

Kawaguchi, D. (2011) Actual age at school entry, educational outcomes and earnings. Journal of the Japanese and International Economics 25:64-80. 
Manacorda, M. (2012) The cost of grade retention. The Review of Economic and Statistics 95:596-606.

Ministerio de Educación (2011) Evaluación General de Diagnóstico 2010: Informe de Resultado. Madrid: Instituto de Evaluación.

OECD (2005) PISA 2003 Data Analysis Manual. SPSS users. Paris: OECD.

OECD (2009) PISA Data analysis manual. SPSS SECOND EDITION. Paris: OECD.

OECD (2010) PISA 2009 Results: What Students Know and Can Do. Paris: OECD.

OECD (2011) Does participation in pre-primary education translate into better learning outcomes at school. PISA IN FOCUS. Paris: OECD.

Ponzo, M. and Scoppa, V. (2014) The long-lasting effects of school entry age: Evidence from Italian students. Journal of Policy Modeling 36:578-99.

Psacharopoulos, G. (2007) The costs of school failure: A feasibility study. European Expert Network on Economics of Education, Monograph.

Rutkowski, L., González, E., Joncas, M. and Von Davier, M. (2010) International Large-Scale Assessment Data: Issues in Secondary Analysis and Reporting. Educational Researcher 39:142-151.

Salinas, J. and Santín, D. (2012) Selección escolar y efectos de la inmigración sobre los resultados españoles en PISA 2006. Revista de Educación 358:382-405.

Sprietsma, M. (2010) Effect of relative age in the first grade of primary school on longterm scholastic results: international comparative evidence using PISA 2003. Education Economics 18:1-32.

Strom, B. (2004) Student achievement and birthday effects. Departament of Economics, Norwegian University of Science and Technology, Trondheim, Norway, mimeo.

Turner, R. (2006) El Programa Internacional para la Evaluación de los Alumnos (PISA). Una perspectiva general. Revista de Educación extra number 2006:45-74. 